Майя ГАРБУЗЮК

\title{
ВОЛОДИМИР ПЕРЕТЦ ПРО РАННЬОМОДЕРНІ ПОЛЬСЬКО-УКРАЇНСЬКО-РОСІЙСЬКІ ТЕАТРАЛЬНІ ЗВ'ЯЗКИ (До історії порівняльного театрознавства в Україні)
}

На основі джерелознавчих пращь видатного ученого окреслено особливості його наукової конщепції театральних міжнаціональних контактів східних слов'ян XVI-XVIII cm. Наголошено на вагомості застосування порівняльно-історичного та контактно-генетичного методів як інструментів для розкриття процесів міжкультурного обміну у сфері драми й театру. Підкреслено принципову позицію ученого щеодо явищ поширення/запозичення/сприйняття/трансформаиї мистещького досвіду як руху зі заходу на схід, із Західної Свропи через Польщу в Украӥну та Росію. Заакиентовано особливу увагу дослідника на вивченні історії духовного театру ляльок (вертепу), зокрема порівнянні його ідейних та структурно-змістових засад, а також відмінних доль вертепного театру у Польщі, Білорусі, Україні та Росії. Зазначено актуальність опрачювання наукової спадщини В. Перетиа як у суто історичному, так і методологічному та світоглядному аспектах.

Ключові слова: історія польсько-украӥнсько-російських мистеиьких зв 'язків, вертепний театр, інтермедія, порівняльні студї в театрознавстві, контактно-генетичний метод.

На основе источниковедческих трудов ученого очерчены особенности его научной конщепџии театральных межнациональных контактов восточных славян XVI-XVIII cm. Отмечена важность применения сравнительно-исторического и контактно-генетического методов как инструментов для раскрытия прочессов межкультурного обмена в сфере драмы и театра. Подчеркнута приниипиальная позиция ученого относительно явлений распространения/заимствования/восприятия/трансформации художественного опыта как движения с запада на восток, из Западной Европьи через Польшу в Украину и Россию. Отдельно отмечено особенное внимание исследователя к изучению истории духовного театра кукол (вертепа), а именно, к сравнению его идейных и структурно-содержательных приниипов, а также несходных судеб вертепного театра в Польше, Беларуси, Украине и России. Подчеркнута актуальность освоения научного наследия В. Перетиа как в историческом, так и в методологическом и мировоззренческом аспектах.

Ключевые слова: история польско-украинско-русских художественных связей, вертепный театр, интермедия, сравнительно-исторический метод в театроведении, контактно-генетический метод.

The main special features of scholar conception of theatrical international contacts of the eastern Slavs of 16-17 c.on the basis of several source studies works are analysed. The importance of usage of comparativehistorical and contact-genetical analysis as an instrument for opening the processes of intercultural exchange in the drama and theatre sphere is emphasized.The general concept of the scholar is underlined on the facts of spreading/borrowing/perception/transformation of artistic experience as a movement from the West to the East, from Western Europe through Poland and Ukraine to Russia.

The text is written with a particular focus on the researcher's attention to the exploration of spiritual puppet theatre (vertep), in particular, comparing its ideologic and structural-content principles as well as difference between the fates of vertep theatres in Poland, Belarus, Ukraine and Russia. The topicality of processing the scientific heritage of V. Peretts in both hystorical and methodological and world-view aspects is considered in the article.

Key words: history of Polish-Ukrainian-Russian artistic relations, vertep theatre, intermedia, comparative studies in theatre studies, contact-genetic method.

Вивчати минуле національного театрознавства варто не лише з міркувань історичних. Вкрай важливим $€$ опанування доробку наших попередників задля з'ясування питання: чи все із того, що поста- 
вало при витоках нашого театрознавства на зламі XIX-початку XX століть, було реалізоване? Чи остаточно вичерпано на сьогодні наукові можливості, що їх закладали у підвалини ще не існуючої на той час театрознавчої науки її вітчизняні першопрохідці - Іван Франко, Володимир Перетц, Михайло Возняк тощо? Йдеться про методологію, точніше - iї історію, що повторила трагічну долю всієї української культури у XX столітті.

Звернімо увагу: сьогодні в Україні маємо такі наукові дисципліни, як «порівняльне літературознавство», «порівняльне мовознавство», «порівняльне правознавство», «порівняльне релігієзнавство». Чому серед них немає «порівняльного театрознавства»? Можливо, його не було взагалі? Або ж коло питань, ключі від яких лежать у царині порівняльних студій, сьогодні неактуальне для вітчизняної науки про театр?

У цій статті спробуємо дати певні відповіді на ці питання - на прикладі окремих праць відомого українського вченого Володимира Перетца (1870-1935), присвячених польсько-українсько-російським літературно-театральним зв'язкам XVI-XVIII століть.

Питання методологічного інструментарію театрознавства в історичному аспекті сьогодні найпослідовніше висвітлює Олександр Клековкін. Саме йому належить честь повернення та актуалізації в українському театрознавстві імені відомого джерелознавця, літературознавця, театрознавця, педагога Володимира Перетца [1, 152-211; 2, 223]. $\mathrm{У}$ зверненні до постаті репресованого ученого О. Клековкін має знаного попередника - Ростислава Пилипчука, котрий ще 1970 року, під охоронною грамотою рішення ЮНЕСКО про відзначення 100-річчя від дня народження В. Перетца, зміг помістити невелику статтю в журналі «Український театр» [3]. Публікації вихованки О. Клековкіна, студентки (нині вже випускниці) кафедри театрознавства Анастасії Коржової [3; 4] та іiі успішно захищена 2017 року магістерська праця [5] дають змогу говорити про найближчі перспективи грунтовного і комплексного опрацювання доробку видатного ученого. Тим часом спробуємо докласти власних скромних зусиль до осмислення наукової спадщини видатного вченого. Звернімо увагу лише на два взаємопов'язаних аспекти у доробку В.Перетца: висвітлення польськоукраїнсько-російських театральних контактів ранньомодерного періоду та застосування методики порівняльних студій для розкриття цих тем.

В. Перетц жив і працював у той щасливий (з нашої точки зору. - M. Г.) період, коли для того, аби аналізувати те чи інше явище чи твір з історії рідної літератури/культури, потрібно було розпочинати «від Адама і Єви», себто вибудовувати контексти, генетичні лінії та історичні паралелі «по вертикалі та горизонталі». В цьому академічному універсалізмі, що розвертав дослідника до світових процесів, яскраво увиразнювалося місце окремо взятих національних культур (цей процес було розпочато ще романтиками у першій половині XIX ст.) - зокрема, через порівняння та встановлення між ними контактно-генетичних зв'язків, через бінарні зіставлення: подібне/відмінне, передане/ сприйняте, своє/чуже, оригінальне/вторинне.

В. Перетц у цьому напрямі продовжував розпочаті братами Веселовськими та підтримані у працях М. Драгоманова, М. Тихонравова, М. Петрова літературознавчі порівняльні студії, в яких знаходили собі місце історія драми й театру. Цілком слушно О. Клековкін у гаслі «Метод порівняльно-історичний (компаративний)» [7, 86-89] пише про дві ключові фігури в історії формування цього методу - видатного російського ученого Олексія Веселовського та російського й українського дослідника історії літератури й театру Володимира Перетца.

Науковий доробок В. Перетца відкриває свою надзвичайну актуальність (і в методологічному, і в змістовому сенсах), щойно нам сьогодні вдається поставити запитання, суголосні за характером із тими, що їх він досліджував понад сто років тому. До таких належить, зокрема, питання про особливості польсько-українських, українсько-російських, польсько-російських зв'язків та впливів у ранньомодерну добу.

На відміну від свого сучасника, з яким він то погоджувався, то дискутував - Івана Франка, - Володимир Перетц мав щастя бути університетським професором (Петербурзький, згодом Ленінградський, університет, Імператорський університет святого Володимира у Києві), викладати історію театру у Петербурзькому університеті та Музично-драматичній школі Миколи Лисенка (нині - Київський національний університет театру, кіно і телебачення ім. І. К. Карпенка-Карого), створити та успішно провадити власний науковий семінар у Київському університеті, з якого постала нова генерація учених, вихованців його наукової школи. Активна педагогічна праця зобов'язувала талановитого Учителя до точного формулювання навчальних та науково-пошукових завдань, а найголовніше - до систематичної, послідовної уваги до питань методології. Про технологію порівняльно-історичних студій у літературознавстві 
В. Перетц у своїй одній 3 найвідоміших праць, друкованій 1922 року, писав, зокрема, так: «Порівняльно-історичний метод полягає в уважному порівнянні у цілому та в частинах літературних пам'яток у межах однієї або кількох різних літератур, беручи до уваги історичну перспективу та хронологічне співвідношення цих пам'яток. Цей метод часто застосовують при аналізі складу i форм літературних творів усіх епох. $<\ldots .>$. Особливо посилилось застосування цього методу тоді, коли стали вивчати народную (усну) словесність європейських народів, порівняно з такою ж-інших народів та писемною традицією, і коли у науковий обіг влився багатющий матеріал східних літератур» $[8,47]$ (тут і далі переклад наш - М. Г.).

Наголосимо, що порівняння ці базувалися не на домислах учених, а на ретельному опрацюванні джерел: театральна текстологія та джерелознавство слугували гарантами точності та коректності застосування компаративних засад. На цьому етапі активного утвердження компаративістики пошук, публікація та коментарі до невідомих досі текстів становили підгрунтя порівняльних студій. Ще однією обов'язковою умовою при цьому було знання кількох іноземних мов (В. Перетц, навчаючись у Петербурзькому університеті, опанував польську, сербську, українську мови $[5,61])$ та робота безпосередньо з історичними документами - текстами. Цікавим у цьому сенсі є окремий епізод із життя В.Перетца, що на нього досі не звернули увагу дослідники, а саме: приїзд В. Перетца до Львова 1907 року та його праця у відомій книгозбірні бібліотеки Оссолінських (нині у цьому приміщенні працює Львівська наукова бібліотека ім. В. Стефаника НАН України, що разом із Національною бібліотекою ім. Оссолінських у Вроцлаві успадкувала фонди заснованої у Львові 1817 року бібліотеки). Ми б, мабуть, мало що знали про цей факт, якби не репліка В. Перетца, висловлена ним на сторінках однієї зі своїх праць 1908 року - учений глибоко обурювався з приводу обмежень для читачів у роботі з документами: за правилами бібліотеки, якщо хтось із дослідників уже публікував виписки з того чи іншого джерела, наступному читачеві це робити вже заборонялося $[9,53] .3$ цієї причини В. Перетц міг подати друком лише фрагменти рукописів інтермедій «Chlop pijany» та «Oszust», оскільки вісім років перед тим їх вже переписав «д-р Крчек», а отже йому й належало право повного публічного друку цих творів (яким він на той час не скористався, що, власне, й обурювало В. Перетца) $[8,53]$. Ця історія не лише акцентує увагу В. Перетца до ори- гінальних текстів, у цьому разі - польських. Набагато важливіше, що публікацію та дослідження цих польських латиномовних джерел В. Перетц вважав за вкрай необхідну справу для вітчизняної науки: «Я мав намір опублікувати їх повністю 3 огляду на їхню важливість для історії української та російської літератури», - 3 гіркотою зазначає дослідник перед тим, як попередити інших про складнощі праці у львівській бібліотеці. До речі, у зв'язку із цим епізодом надзвичайно цікавою й симптоматичною є згадка В. Перетца про одну особу — «незмінно люб'язного бібліотекаря д-ра Бернацького» $[8,53]$. Людвік Бернацький після Кароля Естрайхера був одним із найвідоміших на той час бібліографів польської літератури та театру. Тож, судячи із побіжного відгуку В. Перетца, вони були знайомі щонайменще як «читач» та «бібліотекар», а можливо, й ближче, зважаючи на спільне коло наукових зацікавлень. Ця тема, без сумніву, потребує додаткового вивчення.

Взагалі увага В.Перетца до слов'янських культур була зрозумілою: саме в колі генетично-контактних зв'язків цих літератур можна було точніше й виразніше окреслювати самобутність та місце в європейському констексті двох близьких для нього - української та російської словесності й театру. При цьому його національну й релігійну ідентичності можна назвати радше складними (походив 3 єврейської родини, що свого часу прийняла лютеранство, мешкала в Росії, була споріднена із представниками білоруських та російських заможних сімей). Наукова репутація ученого була бездоганною, а світогляд не підлягав абераціям ані імперської, ані - згодом - комуністичної ідеологій. Навпаки, В. Перетц нерідко виявляв ознаки особистої незалежності від панівних доктрин, а то й спротиву їм (йдеться, зокрема, про його статтю з приводу заснування українських кафедр в університетах, написану і надруковану в Російській імперії 1906 року [19]). Тим важливіше для нас зауважити: жодним чином праці В. Перетца не можна назвати вузькозорієнтованими, вузькоспеціалізованими дослідженнями. Увага вченого була прикута до набагато ширших і складніших процесів міжнаціональних стосунків, впливів, контактів. Тому, розглядаючи теми давньої російської, української, польської літератур, учений заходив у довгі й розлогі генетично-контактні дослідження, $\mathrm{i}$, як справжній компаративіст, говорячи про Схід, він починав із Заходу. Висновки, до яких В. Перетц доходив у результаті своїх досліджень, опертих на студії попередників (К. Вуйціцького, Олексія Веселовського) та сучасників (А. Брюк- 
нера, М. Дашкевича, М. Драгоманова, П. Морозова, М. Петрова, М. Тихонравова, О. Пипіна та ін.) дивують сьогодні своєю актуальністю та прозорливістю, а водночас переконують у тому, що шансів вижити в радянській імперії у нього практично не залишалось. Та про це - згодом...

Показово, що вже одну зі своїх перших праць під назвою «Кукольный театр на Руси» [10] В. Перетц розпочав із широкого розгляду історії театру ляльок у світовому засягу. У вступі, зокрема, він зазначив план викладу: «Сказавши кілька слів про початок театру маріонеток на Заході Європи, ми переходимо до репертуару заїжджих кунштмейстерів, причому намагаємоь якнайповніше ознайомити читача 3 їхніми виставами; потім йдуть глави, присвячені духовному ляльковому театру - вертепу у Польщі, Білій і Малій Росії та його великоросійським відображенням» $[10$, 3]. Тут слід уточнити, що під Білою Росією учений розумів - відповідно до уживаної на той час лексики - сучасну Білорусь, а під Малою Росією, Малоросією, або ж (у подальших прикладах) південно-західною Росією - Україну в ії сучасному географічному окресленні.

Власне, у розділі, присвяченому духовному різновиду театру ляльок, В.Перетц послідовно, спираючись насамперед на джерельні тексти вистав, розглядає польську шопку, білоруську батлейку, український вертеп. Учений комплексно аналізує вертепні видовища, залучаючи текстові джерела, відомості про структуру вертепних скриньок, особивості виготовлення ляльок. При цьому В. Перетц, на відміну від I. Франка, не піддає сумніву твердження Е. Ізопольського про найранішу дату відомого на Україні вертепу - 1591 рік, і це дає йому можливість говорити про існування вертепу в Україні ще наприкінці XVI століття $[10,55]$. Місцем народження українського вертепу В.Перетц вважав «церковно-шкільну обстановку» $[10$, 56], а джерелом походження - принесені із заходу традиції середньовічних церковних містерій. Тож, за В.Перетцом, марштрут поширення цього дійства пролягав із Західної Свропи через Польщу в Україну та Білорусь. Але при цьому для ученого були однаково важливі як моменти прямого запозичення латинських взірців, так і прояви творчого, народного, начала, що й витворювали національно відмінні варіанти вертепних дійств.

Тому В. Перетц вказує, з одного боку — на генетичну спорідненість власне релігійних образів та тем дійства, що становили сворідний міжнаціональний канон, з другого - на низку відмінних рис, сформованих локально. Зокрема, перша - біблійна — частина українського та білоруського вертепного дійства, на думку вченого, зберігає подібну до польської шопки структуру дії та набір персонажів, проте у другій, «народній», інтермедійній за характером, частині, виразно проявляються суто національні риси.

На підставі текстологічних порівнянь, зокрема, фіналу першої частини одного 3 вертепних текстів, учений наголошує подібні та відмінні, питомо національні риси польської, української та білоруської вертепних вистав, підкреслюючи при цьому певну нормативність польської щодо інших національних версій: «Порівнюючи цю частину малоросійського вертепного дійства 3 польськими та білоруськими текстами, ми помічаємо, що при загальному змісті є й оригинальні риси: хори, часом близькі до польських кантичок, деколи цілковито не подібні на них, як за формою, так і за змістом, мова дійових осіб також дослівно не збігається з польськими текстами. П. О. Морозов 3 цього приводу висловлює припущення, що малоросійське вертепне дійство у тому вигляді, в якому його знаємо, складене учнями Київської Академії в часи відносно пізніші, не раніш початку XVIII століття, - складене за взірцем та під впливом польського вертепу. Але так, що цей вплив виявився лише в загальному укладі дії, деталі ж постали оригінальними. Ця думка підтверджується тим, що мова дії відрізняється майже повною відсутністю полонізмів; в силабічному вірші також немає тієї правильності й одноманітності, котрими відзначаються польські вірші та кантички; нарешті, розташування змісту вказує на більшу свободу авторів від теорії, панівної в латинських школах Польщі XVI-XVII віків» $[10,59]$. Показово, що, говорячи про долі цього відлуння середньовічних містерій в різних національних традиціях, В.Перетц простежує усі три варіанти i наголошує на найневдалішій долі білоруської батлейки, упослідженої та гнаної як продукт латиномовної християнської культури і тому мало розвиненої в краї $[10,52]$.

Підкресливши певні нормативні, перенесені 3 польського на український та білоруський грунт засади вертепу (зміст, структура, персонажі), на основі текстологічних порівнянь В.Перетц наголошує мистецьку самостійність та художність українського вертепу в його другій, народній, частині. Спираючись на тексти вертепів Г. Галагана та М. Маркевича, В. Перетц загострює увагу на українських персонажах, зокрема, на образі Запорожця [10, 63-67]. Від уваги дослідника не ховаються важливі деталі національних образів, про- 
явлених у ляльках: він зауважує трансформацію персонажа Польського пана з героїчного у польській шопці на хвальковитого та боягузливого в українському вертепі $[10,62]$. Услід за Г. Галаганом та цитуючи його, В. Перетц захоплено говорить про Запорожця як найбільшу з ляльок українського вертепного дійства $[10,63]$. Спостерігаючи за характером стосунків поміж представниками різних націй, зокрема, польської та української, В. Перетц зауважує і тут, і згодом, у своїй пізнішій праці 1905 року, подібні мотиви. Долучаючи до своїх текстів публікації М. Петрова, Г. Галагана та М. Маркевича, він акцентує: у вертепній драмі, як і в інтермедіях XVII-XVIII ст. незмінно «поляк терпить побої від козака» $[11,58]$. I хоч далі учений ніяк не інтерпретує ці спостережння - ані 3 соціологічного, ані $з$ політичного чи історичного погляду — проте вони дозволяють наголошувати важливі акценти в процесах запозичень/трансформації мистецьких явищ.

Виявляючи генетичні зв'язки та впливи польської духовної театральної культури на культури сусідніх східних народів - білоруську та українську, В. Перетц заперечує думку М. Драгоманова про запозичення української вертепної драми 3 Німеччини. Навпаки, джерелом для першої частини українського вертепу учений називає польську шопку, тоді як друга частина вертепу містить високомистецькі взірці народного театрального мистецтва [10, 76-77]. При цьому для В. Перетца польська та українська вертепна драми мають набагато вищу цінність, аніж західний їх «оригінал»: «Аналіз тексту цих творів польської та малоросійської шкільно-народної словесності показує, що п'єси про Різдво Христове отримали свій справжній вигляд у поляків та південно-русів, незалежно від західноєвропейського взірця, з якого був узятий лише один скелет п'єси, ідея першої, серйозної їі частини» $[10,72]$.

Учений не зупиняється на з'ясуванні лише цих міжнаціональних стосунків. У VII розділі дослідження В.Перетц подає унікальні відомості про поширення українського вертепу в Росії, в сибірських містах Тобольску та Іркутську зокрема. При цьому він наголошує на «принесеному» 3 України характері таких видовищ, а також короткому їх житті, обірваному заборонами на показ вертепів від російської православної церкви. «Хвиля південно-російської освіченості, що заполонила Москву і розлилась Великою Росією, принесла з собою взірці шкільної драми і познайомила 3 ними великоросів», - починає він цей розділ $[10,73]$. I продовжує: «Ця хвиля дійшла i до Сибіру, куди була занесена архієреями 3 малоросів (майже всі кафедри на початку XVIII ст. були зайняті за браком освічених людей, вихованцями Київської Академії, котрі принесли у керовані ними єпархії звичаї та традиції своєї almae matris) $[10,73]$. Розкриваючи причини занепаду принесених у Сибір вертепних традицій, насамперед, гоніння 3 боку російської православної церкви, В. Перетц підсумовує: «Ми бачили долю різдвяної лялькової містерії в Росії; вона розцвіла на півдні, під небом Украйни, дала відблиски в Білорусії, i, занесена до Сибіру, завмерла, з одного боку, під гнітом байдужості до неї народу, з другого — під ударами заборон» $[10,77]$.

Врешті, прокладаючи маршрут поширення вертепного дійства із заходу на схід, із Польщі в Україну та Білорусію, і далі — в Росію, В. Перетц артикулює особливе місце та характер українського вертепу в тривалому історичному процесі передачі/сприйняття/присвоєння/трансформації західного канону. За силою народного творчого начала він ставить український вертеп на сходинку вище, аніж польський: «Оглядаючи на закінчення долі різдвяної містерії на польській та російській лялькових сценах, ми повинні відзначити наступне. Польський вертеп, як і інші, в першій, духовній, частині відтворює Свангельську оповідь, але в другій помітні значні варіації. Друга частина не була пов'язана будь-чим міцно, у неї не було тієї літературної основи, котру мала перша; кожний вертепний театр урізноманітнив іiі; уводячи нові й нові особи, і лише малоросійський піднявся до створення п'єс із загальною думкою, панівною в головному епізоді цієї другої частини. Порівняно 3 ним вистава польської шопки виглядає безбарвною; не кажучи вже про білоруську батлейку, що копіювала то польський, то малоросійський ляльковий театр. У Малоросії театр маріонеток хоч і підлягав літературним впливам, але зостався глибоко народним і за змістом, і за мовою. Польська шопка сприйняла також багато літературних елементів, часом досить пізнього походження, і тому не має тієї стрункості і не створює того цілісного, гармонійного враження» $[10,77]$.

У своїй наступній праці, надрукованій 1899 року, В.Перетц досліджує записи українських пісень XVI-XVII століть і продовжує тему польських впливів на західноруську літературу й освіту, і разом із нею - на великоросійську: «Малороси проникли в Москву ще в XVII столітті, котре в історії російської освіченості позначилось особливо яскраво проявленим західним - переважно польським та малоросійським впливом. 
Порівняно невелика кількість перекладів із західноєвропейських мов XVI ст. цілковито губиться в тій масі, котра належить до XVII століття, головним чином до другої його половини, і серед перекладів - перше місце належить перекладам 3 польської» $[12,93]$. Водночас учений наголошує і вагомість рукописних та друкованих збірників українських і польських народних й авторських пісень: «Майже в усіх збірниках, відомих нам, трапляються пісні штучні та народні малоросійського і польського походження» $[12,101$.$] .$

Важливо, що, розкриваючи тривалі й складні процеси поширення нових поетичних форм із заходу на схід, В. Перетц розуміє усю складність та тривалість цих процесів: «Але польський вплив виявився не одразу: історія його боротьби і лише поступового завоювання свого місця відкривається 3 огляду старовинних інструкцій до віршописання і перебуває у зв'язку із поступовим проникненням польського впливу в училища західної Русі, де спершу переважають слов'яно-еллінські елементи, пізніше - нові віяння, і школи перебудовуються на кшталт католицьких 3 панівними латинською і польською мовою, підручниками та способами навчання» $[12,71-72]$.

Далі В.Перетц наголошує не лише на книжному, літературному впливах, а й суто людському, особистому чиннику як одному з найважливіших у поширенні культури:«Твори малоросійської поезії, як штучної, так і народної, проникали в Москву у XVII-XVIII ст. шляхом збірників, укладених аматорами, але цей шлях не був єдиним: набагато більше значення значення мала безпосередня, усна, жива традиція, тим більш, що співаків, знавців малоруського співу і поезії у Великій Росії, і зокрема в Москві - було чимало» $[12,93]$. В. Перетц говорить про перенесення українського співу до Москви як про тривалий та помітний культурний процес: «Неначе постійним розсадником малоросійського впливу у XVIII ст. продовжували бути півчі, серед котрих було багато малоросів. Перше місце серед хорів посідав придворний. Ми не знаємо усіх його учасників і не можемо вказати усіх малоросів, котрі співали в цьому хорі; обмежимося лише тими нечисленними даними, котрі нам вдалося зібрати...» $[12,99$.$] I далі В. Перетц подає відо-$ мості про українських півчих, задіяних у репертуарі російських театрів: «У 1750 р. 25 листопада була представлена опера Бонеккі й Арайї "Беленофонт", в котрій співав "Ї̈ї Імператорської величності півчий - малоросіянин Марко Федоров (Полторацький)”. В опері “Альцеста” брали участь наступні малороси: Дмитро Бортнянский (Адмет), Семен
Соколовський (Альцеста), Іван Сичевський (Геркулес), Андрій Трубчевский (Меніса), Іван Оробевський (Синор), Федір Ладунка (Плутон), Данило Носаченко (Прозерпина)» [12, 99-100].

Наголосивши вплив польської поезії на формування української у цитованій вище праці, В. Перетц не оминув увагою тему польсько-українських стосунків і надалі. У праці під назвою «Заметки и материалы к истории песни в России», що вийшла друком 1901 року, на основі досліджень польських пам'яток В. Перетц привертає увагу до «дзеркальних» українсько-польських стосунків та впливів. Виникає раніше вже неодноразово артикульована думка ученого про певну симетричність зв'язків: тепер український музичний матеріал він бачить у колі зацікавлення західного - польського - сусіда: «Інтерес поляків - любителів малоросійської літератури до віршів і пісень на малоросійській мові, був, вочевидь, набагато більшим, ніж можна було передбачити за віршами в польських записах, що видані нами 3 примітками у першому томі “Изследовний и материалов"» [13, 9]. Власне, тут дослідник виокремлює цілу групу малоросійських віршів та пісень 3 нотами у польських записах та наголошує на темі поширення i перемоги силабічного римування, що прийшло в Росію з Польщі через малоросійську поезію.

Та, безперечно, найбільшого розкриття тема польсько-українсько-російських театральних стосунків отримала в праці В.Перетца під назвою «До історії польського та російського народних театрів», що виходила друком кількома частинами упродовж 1905-1911 років у Відомостях відділу російської мови та літератури Імператорської академії наук $[9 ; 11 ; 14 ; 15]$. Предметом дослідження тут для В. Перетца стали тексти, знайдені та здебільшого уперше опубліковані ученим, а також ті, що вже були оприлюднені частково або й повністю його попередниками та сучасниками.

«Під час наших занять старовинною малоросійською та польською рукописною літературою, - пише учений у перших абзацах розвідки, - нам вдалося і в галузі театру знайти дещо, що становить інтерес новизни, і в нижчеподаних нотатках ми вважаємо незайве поділитися 3 історикамипольської і російської драматичної літератури деякими отриманими фактами» $[11,53]$. У цій, першій частині об'ємної праці, В. Перетц подав друком кілька інтермедій із вступними до них коментарями. Невеликі за обсягом коментарі містять важливі для нас спостереження. Насамперед, увагу В. Перетца привернули образи селянина (хлопа) в польських та малоросійських інтер- 
медіях, подібні та відмінні риси змалювання цих персонажів «низового театру». 3 цього приводу він, зокрема, зазначає: «Безсумнівно, що спершу у польських авторів зображення простонародних типів було свідомо карикатурним; у той час як у малоросійських письменників XVIII століття народ, гноблений шляхтою і позбавлений права сповідувати релігію батьків і дідів, - зображений 3 глибоким співчуттям та жалістю. Але i ті, й інші, i польські, і малоросійські автори, в цілому непогано відтворюють зовнішню сторону простолюдина, його мову, звичаї, поняття, і тому інтермедії XVII-XVIII ст. окрім літературної цінності становлять немаловажливий матеріал і для етнографа, і для історика мови та культури» [11, 52-53].

До розгляду В. Перетц долучає і «білоруську тему»: «Білорус-селянин — доволі звична фігура в єзуїтських інтермедіях: він простакуватіший та наївніший за малороса, котрий вже на початку XVII ст. потрапив у подібні п'єски з рисами хитрощів та гумору. Услід за низкою білоруських хлопів у зображенні поляків, знаходимо їх і в п'єсах безперечно православного походження» $[11,55]$.

Оцінюючи значення наявності білоруської мови простолюду в польських текстах, В. Перетц вже у заключних розділах праці підсумовує найважливіше:«Ми вже бачили вище (гл.1), як у єзуїтській інтерлюдії в якості блазенської, забавної персони виступав білоруський хлоп, розмовляючи рідною мовою. Ця мова мала здаватись комічною представникам польської культуриXVIII століття. Але тим же польським авторам інтерлюдій, котрі створили цей забавний персонаж - належить мимовільна історична заслуга збереження взірців білоруської мови в темний період iї існування» [14, 274]. Власне, ця оцінка стосується і українського фольклору, уперше на письмі занотованого польськими збирачами пісень наприкінці XVI ст.

Ще один тип персонажів, спільних для інтермедій польських, українських та російських, що його виокремлює В.Перетц - це «пройдисвіт». Учений докладно аналізує зміст та композиційні особливості невідомої польської інтермедії під назвою «Oszust» («Пройдисвіт») з фондів бібліотеки Оссолінських у Львові, а також подає фрагменти самого твору - за неможливістю видрукувати повністю увесь текст через вже згадані заборони керівництва бібліотеки. Зрозуміло, чому таким важливим цей документ був для ученого: в цій інтермедії поруч із Пройдисвітом та Мазуром діє Русин (себто Українець). За сюжетом цей герой з'являється тоді, коли Пройдисвіт у залізних обладунках, не знайшовши для них покупця, прикидається сплячим, аби спровокувати якогось невдаху на крадіжку. Довірливий Мазур підходить, бачить «неживого» чоловіка, співчуває його смерті і збирається ці обладунки зняти. У ту мить, коли Пройдисвіт збирається звинуватити Мазура у пограбуванні, з'являється Русин. Він захищає Пройдисвіта: це дає змогу у кількох репліках висловити усю нелюбов до «псів мазурів», звинувативши їх у злочинах проти Русі. Але в результаті саме Мазур, перехитривши обох, утікає зі зброєю, виявившись спритнішим за Пройдисвіта. В. Перетц подає повністю текст ролі Русина, наголошуючи: «Ми свідомо вилучили (тобто оприлюднили, вийняли з архівного тексту $-M$. Г.) всі промови Русина; зазвичай у польських інтермедіях виступають білоруси, рідше українці. Русин в нашій інтермедії розмовляє місцевою мовою: то чути білорусизми (odzieraty, szto, tobie), то українізми (lypsze, dyali = деяли, больше), то полонізми, зрештою, цілком зрозумілі в польській п'єсі» [9, 63]. На жаль, більше коментарів до безперечно цікавої інтермедії В. Перетц не подає.

Тема Різдва залишається для В. Перетца благодатною територією у генетично-порівняльних дослідженнях. Так, у XX розділі цитованої праці, він докладно пише про звичаї колядування та артикулює, що польські колядки значно раніше проникли у церкву у порівнянні з українськими чи російськими. [15, 39]. 3 цього приводу В. Перетц говорить про відносно однаковий спротив колядуванню різних церков, оскільки зміст коляд найчастіше був надто вільним та легковажним. Проте, говорячи про неможливість зупинити ці секуляризаційні процеси, В.Перетц порівнює і наголошує: «Тоді ми помічаємо на Україні те ж саме явище, що і в Польщі, де духовенство частково поступаючись вимогам пастви саме бере участь у святкуванні, але починає протиставляти непристойним пісням - пісні, відповідні до свята, пісні на релігійно-християнські мотиви. І на Україні особи духовні, що так чи інакше мали стосунок до церкви - починають поступово - можливо, під впливом польських звичаїв, а можливо, піддаючись народним вимогам - засвоювати собі цей звичай колядування і навіть пробують наче монополізувати за собою і взагалі за церковниками і школярами право колядування» $[15,47]$. Звісно, В. Перетц закінчує цю тему поглядом далі - на схід: «На свята Різдва Христового роздавали чимало грошей різдвяним співакам - придворним півчим, серед котрих було у другій половині XVII століття чимало вихідців з України. Цілком природно, що під впливом українських звичаїв і в Москві почали створювати вірші замість древніх 
коляд» $[15,63]$. Згадує при цьому В. Перетц і про так звані «нищенски вирши», і про інші форми публічних виступів: «Як відомо, разом із польським та західноросійським впливом проникає в Москву звичай проголошувати рацеї та діалоги» $[15,63]$.

Того ж року виходить друком критична рецензія В. Перетца на працю В. Рєзанова про театр єзуїтів [16]. Попри довжелезну низку зауважень та в цілому невисоку оцінку праці В. Рєзанова, В. Перетц солідарний із автором монографії у темі польських театральних впливів на схід: «Течії ці досягли Россії за посередництвом Польщі, що засвоювала та відтворювала явища європейського театру у доволі чистому вигляді, частково їх переробляючи відповідно до нових літературних запитів» [16, 16-17]. Підтримуючи думку про впливи єзуїтського театру як вже усталену, В. Перетц звертає увагу на розмаїті акценти, серед яких для нього особливу вагу мають акценти мовні, наявні у ролях Цигана, Жида, Німця, білоруського хлопа-селянина та Українця: ««Згідно 3 теорією шкільного театру білоруський хлоп звичайно розмовляв своїм діалектом, так само, як в польських п’єсах (напр. у Гаватовича) Українець говорив українською мовою» $[16,29]$. Піднімаючи питання вже суто театрознавчого характеру, а саме театральні ефекти, вчений повторює головну думку багатьох своїх та сучасних йому праць: «Великий історико-літературний, а також і історико-театральний інтерес має питання про те, звідки запозичували і український, і московський шкільний театр окремі ефектні моменти та цілі комбінації їх. Головним джерелом, звісно, була спільна традиція театру цього роду, яка переходила через Польщу із Західної Європи» $[16,31]$.

Як свідчать пізніші праці В. Перетца, друковані вже у радянський період, у 1920-ті - першу половину 1930-х рр., своїх поглядів учений не переглядав. Навпаки, акцентуючи на мозаїчності та постійній потребі російської культури запозичувати західні культурні взірці, В.Перетц неодноразово наголошував значення порівняльних інструментів для вивчення російської літератури тамеханізмів іiі формування. «Шляхом порівняння встановлюється, що форма (напр. композиція і стиль), також зберігаючи риси запозичення з того чи іншого знайденого джерел, набуває нових рис, властивих сприймаючому середовищу; така у нас доля галантної лірики, рицарського роману, блазенської комедії, що потрапили до Росії на початку XVIII ст.», — писав він у 1922 році у цитованій на початку відомій праці з питань методології історії російської літератури $[8,38]$. В іншому місці цієї важливої праці В. Перетц зазначив: «Як один 3 методів, що виявляє склад літературних творів, ідейний та формальний, а також їхній зв'язок 3 іншими - порівняльно-історичний метод має велике значення при історико-літературному аналізі не лише пам'ятників старовинної літератури та народної словесності. Лише завдяки його застосуванню можна доказово переконатись, яким був процес творчості “переимчивого Княжнина”, Жуковського, Пушкіна-ліцеїста та багатьох інших письменників нової російської літератури» $[16,49]$. «Переимчивость» російської літератури В. Перетц відкриває не перший, покликаючись на думки свого старшого колеги: «... російський епос, за влучним висловом О.М.Веселовського це "епос міжнародний", як і епос кожного історичного народу. Згодом - російські письменники XVII в. - повторюють польські та українські взірці; верхи літератури XVIII в. - відчувають вплив французьких класиків, російський романтизм стає відлунням романтизму німецького й англійського. Все це з'ясовується шляхом ретельного порівняння творів російської літератури всіх часів, і старої, і нової, з іноземними, але не випадково обраними, а з тими, що виникли до появи подібних до них російських» $[8,47]$.

Навіть коли В. Перетц хибував, не маючи доступу до рукописних джерел, зокрема текстів ранніх шкільних діалогів (маємо на увазі його сумніви щодо існування української шкільної драми наприкінці XVI-початку XVII ст., висловлені у статті «Найдавніша згадка про театр в Україні») - все одно думка про іiі «західне» походження не викликала у нього жодних заперечень [17].

Досліджуючи джерела, а саме тексти вертепних драм, віршів, текстів пісень та інтермедій, В. Перетц переконливо демонструє впливи, що поширювалися з Свропи через Польщу на Білорусь та Україну, звідки діставались далі на схід — до Москви та Великої Росії. Методологічним інструментарієм для цих студій слугує історично-порівняльний метод, що ним учений володів бездоганно.

3 наведених висловів В. Перетца неможливо не помітити особливу увагу, яку він приділяв саме місцю української культури, літератури, театру у цих складних процесах ретрансляції західного досвіду, сприйнятого, творчо переосмисленого, синтезованого з національними первнями та перенесеного на схід, до Великої Росії. Не менш важливими акцентами у доробку ученого $\epsilon$ виявлення «симетричних» зацікавлень Україною як у західних сусідів (Польща), так і східних (Росія). За імпліцитно наявним у наукових текстах В. Пе- 
ретца культурним ландшафтом не складно помітити, що своєрідним географічним та ментальним центром його «внутрішньої мапи»є радше Україна — «Украйна», як він пії називає, - аніж Росія. Можна у цьому сенсі, звісно обережно, говорити про певний «україноцентризм» В. Перетца - тим дивніший, що висловлений аполітичним дослідником, російською мовою та здебільшого з теренів не українських.

Слід наголосити, що лексика В. Перетца запозичення, сприймання та ін. $-\epsilon$ не лише робочим інструментарієм компаративіста, а й значною мірою провіщає, перегукується із постколоніальними студіями, що розвинулись як галузь гуманітарного міждисциплінарного знання набагато пізніше, у другій половині XX ст. 3 цієї точки зору праці В. Перетца ще потребують подальшого вивчення. Хоча вже зараз цілком очевидними $\epsilon$ його науково обгрунтоване, ідеологічно незаангажоване і багато в чому мимовільне деконструювання імперського міфу вищості та винятковості російської культури, літератури й мистецтва. Не ставлячи собі цього за мету, учений, одначе, дослідним шляхом доходить висновків, що лише сьогодні опиняються в центрі уваги наукової спільноти. Тож чи варто дивуватися - в цьому контексті - 3 трагічної долі вченого у добу сталінських репресій, адже він так чи інакше сприяв підриву засадничих імперських та тоталітарних міфів. Саме тому він та його школа були приречені: про це докладно, спираючись на архіви СБУ, розповіла у своїй статті А. Коржова [18].

Науковий світогляд неважко виявити у працях вихованців театрознавчої школи Перетца А. Адріанової-Перетц, Петра Руліна, Костя Копержинського, Івана Огієнка та ін. Його думки були суголосні працям М. Возняка, з котрим вів активне спілкування. Перебуваючи у наукових дискусіях з І. Франком, посутньо В. Перетц, проте, був близьким до галицького колеги саме широтою та точністю розуміння міжнаціональних культурних процесів, у яких долі театру посідали не останнє місце. Ці підвалини лягли в основу національної концепції історії українського театру професора Р. Пилипчука вже у часи Незалежності. Хоча - на нашу думку — деякі акценти в ній, що привертали увагу В. Перетца зокрема, мали б сьогодні отримати виразніше артикулювання.

Так, розпочавши свої наукові зацікавлення $з$ російської культури й театру, В. Перетц як учений послідовно прийшов до питань ії зв'язків 3 українською, а разом з Україною в коло його уваги неминуче увійшла польська поезія, драма, шопка - як західне джерело впливу, як ретранслятор європейського сценічного досвіду. Тема полоністики В. Перетца ще не відкрита до кінця і чекає дослідників. Так само, як і порівняльно-історичний метод, репресований разом із його видатним «носієм», потребує нашої пильної уваги.

Час ставити запитання, подібні до тих, які піднімав В. Перетц щодо ранньомодерної доби. Потребує оновлення наша дослідницька оптика - задля безстороннього та об'єктивного погляду на міжнаціональні, міжкультурні театральні процеси, в які було залучено/з яких було вилучено український театр упродовж XIX ст. ХХ століть.

Озброївшись історично-порівняльною ретроспективою, вийшовши за межі власне історії українського театру та піднявшись над європейським простором вище, «на висоту Перетца», маємо змогу у явищах наступного, XIX ст. відкрити триваючу в культурі «інерцію» руху та механізми впливів, напрацьовані попередніми століттями. Для цього треба лише відповісти на питання про зв'язки української театральної культури з російською, наприклад, про значення творчості М. Щепкіна та театру корифеїв у процесах формування таких визначних явищ російської культури XIX ст. як Малий театр та МХAT.

$\mathrm{У}$ цьому сенсі слід поглянути й ближче, у століття XX-те, аби востанне простежити напрям інноваційного театрального руху із заходу на схід, лише тепер уже - в межах Радянської України. Йдеться про Леся Курбаса та його колег по цеху - групу галицьких акторів, котрі разом 3 однодумцями здійснили останню в українському театрі революцію, інспіровану західноєвропейським досвідом.

Iз заснованих на джерелознавчих та порівняльно-історичних театрознавчих працях українських учених кінця XIX-початку XX ст. висновків випливають важливі уроки нашого сьогодення. Реанімувавши активний діалог із європейським театром, ми знову - як кілька століть тому, отримаємо можливість отримувати/приймати/трансформувати/перетворювати (і заперечувати, якщо треба) його досвід, вибудовуючи власний. Досліджуючи ці процеси в історичному аспекті, ми будемо здатні оновити нашу науково-світоглядну мапу та змістити центри тяжіння, усвідомивши при цьому своє місце та вагу. Можливо, таким би й був заповіт В. Перетца, якби він заговорив сьогодні до нас? 


\section{Джерела та література}

1. Клековкін О. Театр при столику. Методологія театрознавства / Олександр Клековкін. - К. : Фенікс, 2013. 432 с. / Школа Володимира Перетца - С. 152-211.

2. Клековкін О. Історіографія театру: Напрями. Школи. Методи. Постаті : Навчальний посібник / Олександр Клековкін / Київський національний університет театру, кіно і телебачення ім. І.К. Карпенка-Карого. — К. : АркЕк, 2017. - $336 \mathrm{c}$.

3. Пилипчук Р. Славетний історик театру: [До 100-річчя від дня народження В.М. Перетца] / Ростислав Пилипчук // Український театр. - 1970. - № 1. - С. 31.

4. Коржова А. Школа театрознавства Володимира Перетца / Анастасія Коржова // Просценіум. - Львів, 2013. № 1-3 (38-40). - С. 122-125.

5. Коржова А. Дискусія між Володимиром Перетцом і Володимиром Рєзановим: два напрями дослідження історії театру // Сучасні дослідження в галузі культури і мистецтва. - К. : КНУТКіТ ім. І. К. Карпенка-Карого, 2017. C. 34-37.

6. Коржова А. Методологія Володимира Перетца у контексті театрознавства $1890-\mathrm{x}-1930$-х років: типологічне дослідження. Магістерська робота. - Рукопис. - 254 с. Зберігається на кафедрі театрознавства Київського національного університету театру, кіно і телебачення ім. І. К. Карпенка-Карого.

7. Клековкін О.Дискурс про театр. Історіографічний словничок / Олександр Клековкін; передм. А. О. Пучкова ; Ін-т проблем сучасного мистецтва НАМ України. — К. Арт Економі, 2016. - 136 с.

8. Перетц В. Краткий очерк методологии истории русской литературы. Пособие исправочник для преподавателей, студентов и для самообрадования / В.Н. Перетц. - Петроград : Academia, 1922. - $164 \mathrm{c}$.

9. Перетц В. К истории польского и русского народного театра. XVIII-XIV / В. Перетц // Известия Отделения русского языка и словесности Императорской академии наук. 1907 [г.] - Спг., [б. в.], 1908. - Т. XII. - Кн. 4. C. $52-86$.

10. Перетц В. Кукольный театр на Руси. Исторический очерк // Ежегодник императорских театров. Сезон 1893 1894. - СПб : Типография Императорских Санкт-Петербургских театров, 1894. - Приложение. - Кн. 1. C. $85-185$.

11. Перетц В. К истории польского и русского народного театра, I-VII (Несколько интермедий XVII-XVIII ст. Посвящается памяти А. Н. Пыпина) / В. Перетц // Известия Отделения русского языка и словесности Императорской академии наук. - Спг., [б. в.], 1905. - Т. Х. - Кн. 1. C. 51-104.

12. Перетц В. Малорусские вирши и песни в записях XVIXVII веков. XV-XXII / Перетц В. К. - Санкт-Петербург, 1899. $-156 \mathrm{c}$.

13. Перетц В. Заметки и материалы к истории песни в России. I - VIII / Перетц В. К. - Санкт-Петербург : Типография Императорской Академии наук, 1901. - 83 с.

14. Перетц В. К истории польского и русского народного театра, XVIII-XIX / В. Перетц // Известия Отделения русского языка и словесности Императорской академии наук. Спг., [б. в.], 1911. - Т. XVI. - Кн. 3. - С. 248-319.

15. Перетц В. К истории польского и русского народного театра (Окончание)/ В. Перетц // Известия Отделения русского языка и словесности Императорской академии наук. - Спг., [б. в.], 1911. - T. XVI. - Кн. 4. - С. 39-66.

16. Перетц В. Новый труд по истории украинского театра. СПб. : Сенатская типография, 1911. - 42 с.
17. Перетц В. Найдавніша згадка про театр в Україні // Україна. - К., 1924. - Кн. 1-2. - С. 14-15.

18. Коржова А. До наукової біографії В. М. Перетца, історика театру / А. Коржова // Мистецтвознавство України. 2016. - Вип. 16. - С. 38-56.

19. Перетц В. К вопросу об учреждении украинских кафедр в университете / В. Перетц // Киевская старина. - К. : Типография Императорского университета св. Владимира, 1906. 一 № 5-6. - C. 43-49.

\section{References}

1. Klekovkin, O. Teatr pry stolyku. Metodolohiia teatroznavstva/ Oleksandr Klekovkin. — K. : Feniks, 2013. — 432 s.

2. Klekovkin, O. Istoriohrafiia teatru: Napriamy. Shkoly. Metody. Postati : Navchalnyi posibnyk / Oleksandr Klekovkin / Kyivskyi natsionalnyi universytet teatru, kino i telebachennia im. I. K. Karpenka-Karoho. - K. : ArkEk, 2017. - $336 \mathrm{~s}$.

3. Pylypchuk, R. Slavetnyi istoryk teatru : [Do 100-richchia vid dnia narodzhennia V. M. Perettsa] / Rostyslav Pylypchuk // Ukrainskyi teatr. - 1970. - № 1. - S. 31.

4. Korzhova, A. Shkola teatroznavstva Volodymyra Perettsa / Anastasiia Korzhova // Prostsenium. — Lviv, 2013. - № 1-3 (38-40). - S. 122-125.

5. Korzhova, A. Dyskusiia mizh Volodymyrom Perettsem i Volodymyrom Riezanovym: dva napriamy doslidzhennia istorii teatru // Suchasni doslidzhennia v haluzi kultury i mystetstva. - K. : KNUTKiT im. I. K. Karpenka-Karoho, 2017. - S. 34-37.

6. Korzhova, A. Metodolohiia Volodymyra Perettsa u konteksti teatroznavstva 1890-kh-1930-kh rokiv: typolohichne doslidzhennia. Mahisterska robota. - Rukopys. - 254 s. - Zberihaietsia na kafedri teatroznavstva Kyivskoho natsionalnoho universytetu teatru, kino i telebachennia im. I. K. Karpenka-Karoho.

7. Klekovkin, O.Dyskurs pro teatr. Istoriohrafichnyi slovnychok / Oleksandr Klekovkin; peredm. A. O. Puchkova ; In-t problem suchasnoho mystetstva NAM Ukrainy. - K. : Art Ekonomi, 2016. - $136 \mathrm{~s}$.

8. Peretts, V. Kratkiy ocherk metodologii istorii russkoy literaturyi. Posobie i spravochnik dlya prepodavateley, studentov i dlya samoobradovaniya / V.N.Peretts. Petrograd : Academia, 1922. - $164 \mathrm{~s}$.

9. Peretts, V. K istorii polskogo i russkogo narodnogo teatra. XVIII-XIV / V.Peretts // Izvestiya Otdeleniya russkogo yazyika i slovesnosti Imperatorskoy akademii nauk. 1907 [g.] — Spg., [b. v.], 1908. — T. XII. — Kn. 4. - S. 52-86.

10. Peretts, V. Kukolnyiy teatr na Rusi. Istoricheskiy ocherk // Ezhegodnik imperatorskih teatrov. Sezon 1893-1894. $\mathrm{SPb}$ : Tipografiya Imperatorskih Sankt-Peterburgskih teatrov, 1894. - Prilozhenie. - Kn. 1. - S. 85-185.

11. Peretts, V. K istorii polskogo i russkogo narodnogo teatra, IVII (Neskolko intermediy XVII-XVIII st. Posvyaschaetsya pamyati A. N. Pyipina) / V. Peretts // Izvestiya Otdeleniya russkogo yazyika i slovesnosti Imperatorskoy akademii nauk. - Spg., [b. v.], 1905. - T. X. - Kn. 1. - S. 51-104.

12. Peretts, V. Malorusskie virshi i pesni v zapisyah XVI-XVII vekov. XV-XXII / Peretts V. K. — Sankt-Peterburg, 1899. — $156 \mathrm{~s}$.

13. Peretts, V.Zametki i materialy $\mathrm{k}$ istorii pesni $\mathrm{v}$ Rossii. I - VIII / Peretts V. K. - Sankt-Peterburg : Tipografiya Imperatorskoy Akademii nauk, 1901. $83 \mathrm{~s}$.

14. Peretts, V. K istorii polskogo i russkogo narodnogo teatra, HVIII-HIH / V.Peretts // Izvestiya Otdeleniya russkogo yazyika i slovesnosti Imperatorskoy akademii nauk. - Spg., [b. v.], 1911. - T. XVI. - Kn. 3. - S. 248-319. 
15. Peretts, V. K istorii polskogo i russkogo narodnogo teatra (Okonchanie) / V. Peretts // Izvestiya Otdeleniya russkogo yazyika i slovesnosti Imperatorskoy akademii nauk. - Spg., [b. v.], 1911. - T. XVI. - Kn. 4. - S. 39-66.

16. Peretts, V. Novyiy trud po istorii ukrainskogo teatra. - SPb. Senatskaya tipografiya, 1911. - $42 \mathrm{~s}$.

17. Peretts, V. Naidavnisha zghadka pro teatr $\mathrm{v}$ Ukraini // Ukraina. - K., 1924. - Kn. 1-2. - S. 14-15.
18. Korzhova, A. Do naukovoi biohrafii V. M. Perettsa, istoryka teatru / A. Korzhova // Mystetstvoznavstvo Ukrainy. 2016. - Vyp. 16. - S. 38-56.

19. Peretts, V. K voprosu ob uchrezhdenii ukrainskih kafedr v universitete / V. Peretts // Kievskaya starina. - K. : Tipografiya Imperatorskogo universiteta sv. Vladimira, 1906. 一 № 5-6. - S. 43-49. 